oddzialywanie-na-powstanie-tresc-i-wykonywanie-praw-wlasnosci-intelektualnej-arkadiusz-michalakdarmowy-fragment.pdf.

11. RudolfKlostermann. DiePatent-gesetzgebung allerländer.URL:https://books.google.com.ua/ books?id=GMclWSzIbkAC\&pg=PA262\&lpg=PA262\&dq=Patentgesetz $+\% \mathrm{C} 3 \% 96$ sterreich $+1852 \&$ source $=$ bl\&ots $=$ ZkegI9CWDd\&sig $=91$ aa6keTYF9ri9ZVezGTwZfqTGg\&hl $=$ ru\&sa $=$ X\&ved $=$ 2ahUKEwiCper3iNTfAhVtwIsKHYJiCHYQ6AEwBHoECAYQAQ\#v=onepage\&q=Patentgesetz $\%$ $20 \% \mathrm{C} 3 \% 96$ sterreich $\% 201852 \& \mathrm{f}=$ false.

12. Strafgesetz 1852 (Österreich). URL: https://de.wikisource.org/wiki/Strafgesetz_1852_ (\%C3\%96sterreich).

УДК $351 / 354 ; 34.07$

DOI https://doi.org/10.32844/2618-1258.2019.5-2.3

ТИХОМИРОВ Д.О.

\title{
ДЕЯКІ АСПЕКТИ ОСМИСЛЕННЯ БЕЗПЕКИ ТА ЇЇ ГАРАНТІЇ
}

У статті осмислюються проблеми плюралістичності наукового та нормативно-правового розуміння понять безпека, небезпека та гарантія безпеки. 3'ясовуються особливості їх співвідношення та змістовного наповнення. Метою статті $\epsilon$ осмислення окремих аспектів розуміння безпеки, небезпеки та гарантії безпеки, правової безпеки зокрема. Методологія дослідження склала сукупність методів, які охоплюють: діяльнісний, метод герменевтики, метод порівняння та метод абстрагування. У «статичному» розумінні безпека розглядається в зіставленні з певними об'єктами (матеріальним та нематеріальними) та суб'єктами як їх характеристика (властивість) риса. В «динамічному» розумінні безпека пов'язується з певною діяльністю, спрямованою на безпеку (ії суб'єктами, засобами, заходами, нормативами, метою тощо), інакше кажучи, на гарантію (захист, охорону) безпеки. 3'ясовано, що в разі обмеження чи уточнення поняття «безпека» набуває всеохоплюючого характеру чи значення, і важко виявити ті явища та процеси, які не охоплюються цим поняттям. 3 іншого боку, неможливо виключати такий аспект розуміння безпеки. Безпека та їі гарантія в різних варіаціях співвідноситься з існуванням, розвитком, цілісністю, незалежністю, спокоєм об'єкта безпеки та відсутністю небезпеки (загроз, ризиків). Безпека і небезпека мають взаємозалежні виміри, відносні одне одного значення. Так, безпека - це відсутність небезпеки, небезпека за своїм впливом на безпеку - гранична, неприпустима, надмірна, мінімальна, обмежена до прийнятного рівня. Проблеми правової безпеки та ії гарантія потребують подальшого наукового осмислення й не тільки в напрямі з'ясування загального з їх міждисциплінарним розумінням, але й виявлення своєрідності саме правового розуміння, його імплементації в понятійно-категоріальний апарат юридичної науки, зокрема через співвідношення з такими традиційними юридичними науковими конструкціями як правопорядок, злочинність, правовий вплив, правове регулювання, функції права та держави, гарантії тощо.

Ключові слова: безпека, небезпека, загрози, захищеність, законодавство, забезпечення безпеки, об 'єкти безпеки, суб'єкти безпеки.

The article deals with the problems of pluralistic scientific and regulatory understanding of the concepts of safety, danger and security. The peculiarities of their correlation and content are explained. Goal. The purpose of the article is to understand some

(С) ТИХОМИРОВ Д.О. - кандидат юридичних наук, докторант докторантури та аспірантури (Національна академія внутрішніх справ) 
aspects of understanding security - dangers and security, legal certainty in particular. Methods. The methodology of the study was a set of methods including: activity, method of hermeneutics, method of comparison, and method of abstraction. Conclusions. In the "static" sense, security is considered in relation to certain objects (tangible and intangible, subjects) as their characteristic (property) trait. In a "dynamic" sense, security refers to a specific activity aimed at security (its subjects, means, measures, standards, purpose, etcetera), in other words, to provide (protection, protection) security. It has been found that, in the case of limitation or refinement, the concept of "security" acquires a comprehensive character or meaning, and it is difficult to identify those phenomena and processes that are not covered by this concept, and on the other hand, it cannot be excluded. Security and its security in different variations correlate with existence, development, integrity, independence, peace of mind of the object of safety and absence of danger (threats, risks). Safety and danger are interrelated dimensions that are relative to one another. Yes, security is the absence of danger, danger in its impact on security is marginal, unacceptable, excessive, minimal, limited to an acceptable level. The problems of legal certainty and its security require further scientific understanding, not only in the direction of finding common ground with their interdisciplinary understanding, but also in identifying the peculiarity of the legal understanding itself, its implementation in the conceptual and categorical apparatus of legal science, in particular through its relation with such traditional legal jurisdictions. Constructions such as law and order, crime, legal influence, legal regulation, functions of law and state, guarantees, etc.

Key words: security, danger, threats, legislation, security, security facilities, security entities.

Вступ. Проблематика безпеки в науковому мисленні досліджувалась ще 3 часів античності. Зміни суспільства, розвиток людства, науково-технічний прогрес привносили свої особливості до інтерпретації цього терміну. При цьому привертає увагу те, що частина досліджень проблематики носять міжгалузевій характер. Проте залишаються дещо невизначеними певні фундаментальні категорії, які стосуються безпеки та її гарантія, й, відповідно, виникає потреба у їх дослідженні.

Теоретичну основу становлять праці таких учених як: В.Т. Білоус, О.С. Бодрук, В.І. Борисов, О.П. Дзьобань, В.С. Зеленецький, І.В. Зозуля, М.І. Камлик, В.С. Картавцев, В.В. Кузнецов, М.I. Мельник, А.А. Музика, П.П. Михайленко, Н.Р. Нижник, М.І. Панов, В.С. Сідак, Г.П. Ситник, О.В. Украінчук,

Постановка завдання. Метою статті є осмислення окремих аспектів розуміння безпеки, небезпеки та гарантії безпеки, зокрема правової безпеки.

Результати дослідження. Натепер існує різноманітність варіантів як наукового розуміння, так і нормативно-правового визначення безпеки та ії гарантії. Так, плюральність наукового розуміння безпеки залежить як від галузі знань, у контексті якої досліджується безпека, так і від особливостей контекстового розуміння безпеки (конкретного його виду). Власне, поняття безпека розуміється як стан захищеності, свобода від небезпеки або ризику, фактор, необхідний для сталого розвитку суспільства, оскільки охоплює всі сфери людської діяльності тощо.

У цьому контексті безпека розуміється як: соціальне явище; атрибут об'єкта і суб'єкта; стан об'єкта, який містить в собі наявність або можливість настання небезпечних подій та їх несприятливі наслідки; властивість або критерій якості соціальної системи; умови діяльності; система заходів, що забезпечують захист об'єкта від небезпечних впливів; соціальна мета, яка виражається через сукупність внутрішніх зв'язків системи і спрямована на ії стійкий і прогресивний розвиток; діяльність уповноважених державних органів та інших суб'єктів.

Різноманітність інтерпретацій терміну «безпека» властива і нормативно-правовому його розумінню. Законодавство, у вузькому розумінні терміну «безпека», дає визначення правовим категоріям національної, авіаційної, пожежної, громадської безпеки тощо, проте загального поняття «безпека» не містить.

За даними Верховної Ради України, термінологія законодавства нині охоплює 375 термінів, які стосуються безпеки загалом, іiі окремих видів та взаємопов'язаних правових явищ (понять). Так, у Законі України «Про національну безпеку України» національна безпека визначається як «захищеність державного суверенітету, територіальної цілісності, демократичного конституційного ладу та інших національних інтересів України від реальних та потенційних загроз». Тер- 
мін «захищеність» щодо життєво важливих національних інтересів або життєво важливих для суспільства та особи інтересів, прав і свобод людини і громадянина від реальних і потенційних загроз використовується у визначеннях державної безпеки, воєнної безпеки, громадської безпеки й порядку [1]. В інших нормативно-правових актах безпека визначається через стан, відсутність ризику або загроз, властивість чи здатність об’єкту, межі тощо. В усіх цих варіаціях спільним є розуміння, що безпека - це певна характеристика об'єкта чи суб'єкта.

Дослідження цього плюралізму, спільного та відмінного в інтерпретаціях поняття «безпека» має значення для формування відповідного розуміння в юридичних науках, оскільки дає можливість з'ясування загального, особливого та своєрідного в межах співвідношення не тільки між юридичними та іншими соціально-гуманітарними науками, але й між нормативно-правовими визначеннями безпеки в законодавстві.

Аналіз визначень розуміння безпеки, що існують як у соціально-гуманітарних, зокрема юридичних, науках, так і в нормативно-правових актах, свідчить про те, що безпека, як правило, характеризується з використанням таких парних термінів або таких площин (ракурсів) як: стан діяльність, внутрішнє - зовнішнє, присутність - відсутність, об'єкт (суб'єкт) - середовище, явище - процес, корисне-шкідливе, абсолютне - відносне (міра, ступінь, рівень), наявність - можливість, якість - кількість та інших.

Багатоманітність варіантів розуміння небезпеки, іï співвідношення з загрозами, а останніх з ризиками, властиве і їх інтерпретаціям у науці. Так, за умови, що безпека розглядається як «відносний стан, за якого всі системи суб'єкта чи об'єкта можуть працювати з максимальною ефективністю», то «ризик є умовою появи небезпеки», причому остання є «поняттям можливості, вона $є$ гіпотетичною, тобто може бути прихованою або тільки передбачуваною», тоді як загроза «це вже реальна подія, за якої небезпека переходить зі стану можливості в реальну площину», «загроза - конкретна й безпосередня форма небезпеки або комплекс передумов і факторів, які створюють небезпеку інтересам суспільства, держави, індивіда, а також національним цінностям» [2, с. 150]. Виходячи з цього, небезпека визначається як «імовірність заподіяння шкоди об'єкту економічної безпеки, яка перебуває в динамічному стані й постійно змінюється залежно від конкретних ризиків, загроз у наявних обставинах» [3, с. 96]. На ймовірність, пасивну форми небезпек, та активну форму, конкретність, безпосередність загроз, значення небезпек і загроз як факторів ризику звертають увагу й інші вчені $[3,4]$. Проте існує й позиція вчених, які вважають, що ризик $є$ первинним поняття, але небезпека, навпаки, випливає із загроз і $є$ їх конкретним проявом [6], не потенційною, а реально негативною дією[7].

У нормативно-правовому розуміння небезпека формулюється здебільшого як потенційне джерело, сукупність факторів або будь-які умови, заходи чи обставини, здатні чинити негативний вплив на людей та довкілля або які можуть стати причиною катастрофи, інциденту, аварії тощо [8-10]. В такому варіанті вона фактично ототожнюється із загрозами. Так, «Загрози національній безпеці України - явища, тенденції і чинники, які унеможливлюють чи ускладнюють або можуть унеможливити чи ускладнити реалізацію національних інтересів та збереження національних цінностей України» [1]. Близьким до цього визначення загроз їх розуміння як наявних та потенційно можливих явищ і чинників, що негативно впливають на суспільні відносини, $є$ і в інших нормативно-правових актах України. Наведемо їх: «Загроза - наявні та потенційно можливі явища і чинники, що негативно впливають на сферу безпеки державного кордону» [11], «Терористична загроза - існуючі та потенційно можливі чинники, які створюють небезпеку вчинення терористичного акту щодо об'єкта можливих терористичних посягань та настання негативних наслідків від нього» [12] або «Кіберзагроза - наявні та потенційно можливі явища й чинники, що створюють небезпеку життєво важливим національним інтересам України в кіберпростоpi, справляють негативний вплив на стан кібербезпеки держави, кібербезпеку та кіберзахист іiі об'єктів» [13].

У Хіогській рамковій програмі дій на 2005-2015 рр. небезпека визначається як «потенційно згубне фізичне явище, подія або діяльність людини, які можуть призводити до загибелі людей або нанесення їм тілесних ушкоджень, заподіяння шкоди майну, порушення функціонування соціальних й економічних систем або погіршення стану довкілля. Небезпеки можуть містити приховані умови, що несуть у собі майбутні загрози, і можуть зумовлюватися різними причинами: природними (геологічними, гідрометеорологічними і біологічними) або викликаними процесами життєдіяльності людини (погіршення стану довкілля і техногенні небезпеки)» [14].

Таким чином, у контексті поставленого завдання, а саме співставлення понять безпека та небезпека, можна стверджувати, що вони пов'язані між собою як термінологічно (ети- 
мологічно), так і змістовно. У всіх варіаціях розуміння безпеки їі характеристика неможлива без використання тим або іншим чином понять небезпека, загроза, ризик тощо, причому безпека охоплює останні через їх відсутність або присутність як наявність чи можливість у певному обсязі, щонайменше мінімальному (наявність може бути й відсутня, але можливість не може бути виключена). Власне, як і небезпека не може бути охарактеризована без використання поняття «безпека», їх недоцільно співвідносити як ціле та частина, оскільки небезпека - це протилежність безпеці.

Ці слова є однокореневими антонімами, оскільки не тільки володіють різними ознаками, але й пов'язані один з одним через виключення, заперечення один одного. Вони взаємовиключають, заперечують один одного, докорінно взаємно протистоять один одному, але не можуть один без одного існувати. Загальновідомо, що з позицій діалектики протилежності як взаємозв'язані сторони єдиного, які одночасно покладають і виключають одна одну, знаходяться у відношенні єдності і «боротьби», а боротьба протилежностей - це процес їх взаємовиключення в рамках єдності, конкретний механізм якого визначається природою явища, яке розвивається. Як протиріччя їх доцільно розглядати щонайменше у двох варіантах: протиріччя зовнішні - протиріччя між різними предметами, явищами; протиріччя внутрішні - протиріччя між протилежними сторонами одного й того ж предмета, явища.

Із цих філософських положень випливає й інше - неможливість існування безпеки чи небезпеки без прив'язки до об'єктів; якщо ж говорити про людську діяльність - до суб'єктів, які знаходить своє втілення, зокрема, у виокремленні об'єктів та суб'єктів безпеки/небезпеки, зовнішньої та внутрішньої безпеки/небезпеки тощо.

У цьому ж контексті можлива інтерпретація розвитку як результату «боротьби» цих протилежностей (протиріч). Так, суспільний розвиток «є результатом складної взаємодії багатьох процесів. Причому деякі з них не мали нічого спільного із прогресом, а деякі взагалі виявилися регресивними» $[15$, с. 18$]$.

Такий аналіз можливий також щодо таких понять як наявність (присутність) - відсутність. які констатують або заперечують факт існування предметів, явищ, подій [16, с. 171], наявність та можливість та інших, що використовуються у формулюваннях безпеки.

Подібно до розуміння безпеки, не менш плюралістичним $є$ наукове і нормативно-правове розуміння забезпечення безпеки, змістовне наповнення яких варіюється в залежності від певного розуміння безпеки, галузі юридичної науки або галузі права, співвідношення зі спорідненими поняттями тощо.

В законодавстві забезпечення інтерпретується найчастіше як комплекс, сукупність заходів чи дій, які потрібні, необхідні, спрямовані на досягнення впевненості, відповідності певної діяльності визначеним нормам, правилам, вимогам. На відміну від зазначених та подібних варіантів формулювань, гарантія безпеки в різних варіантах використання цього терміну орієнтовано, перш за все, на запобігання загрозам, небезпекам, впливам негативних факторів, пов'язується із захистом чи охороною. Зокрема, в законі України «Про основи національної безпеки України» (який утратив чинність на підставі Закону України № 2469-VIII від 21.06.2018) національна безпека пов'язувалася із захищеністю життєво важливих інтересів людини і громадянина, суспільства і держави, за якої забезпечуються:

1) сталий розвиток суспільства;

2) своєчасне виявлення, запобігання і нейтралізація реальних та потенційних загроз національним інтересам у різних сферах державного управління при виникненні негативних тенденцій до створення потенційних або реальних загроз національним інтересам.

Як бачимо, на обмеження національної безпеки та ії гарантії тими сферами суспільного життя, в яких можливі або наявні загрози, спрямовано й формулювання сектору безпеки й оборони як системи органів державної влади, Збройних сил України, інших, утворених відповідно до законів України, військових формувань, правоохоронних, розвідувальних та інших органів, сил оборонно-промислового комплексу, громадян та громадських об'єднань, діяльність яких за функціональним призначенням спрямована на захист від загроз національних інтересів України [1].

Якщо під безпекою розуміти існування об'єкта без обмежень, то це поняття набуває всеохоплюючого характеру чи значення, і важко виявити ті явища та процеси, які б не охоплювалися цим поняттям. 3 іншого боку, неможливо виключати такий аспект розуміння безпеки. Варіантом розв'язання проблеми є обмеження цієї сфери прояву безпеки тими соціальними явищами та процесами, в межах яких або щодо яких існують або можуть існувати потенційні чи наявні загрози (небезпеки). 
Правова безпека. Зазначені вище положення щодо інтерпретацій безпеки в нерозривності $з$ небезпекою, диференціація безпеки та їі гарантія мають теоретичне значення для розуміння понять правова (юридична) безпека та правова гарантія безпеки, їх співвідношення 3 такими традиційними поняттями юридичної науки як правопорядок та злочинність тощо.

В юридичній літературі викладені різні позиції вчених щодо розуміння правової безпеки.

Одні дослідники вважають, що юридична безпека - це стан юридичної захищеності життево важливих інтересів особистості (суспільства і держави) від зовнішніх і внутрішніх загроз [17].

Інші в розумінні правової безпеки акцентують увагу фактично на правовій гарантії безпеки, вважаючи, що «правова безпека покликана забезпечити захищеність національних інтересів, опосередкувати всі види безпеки» [18]. Ще одні наполягають на тому, що правова безпека - це способи, умови, які гарантують всебічну захищеність правового стану людини в суспільстві [19]. Існує думка, що правова безпека - стан захищеності життєво важливих інтересів особи від зовнішніх і внутрішніх загроз у сфері правових відносин [20].

Третя група вчених поєднує інтерпретації правової безпеки як правової захищеності національних інтересів, захищеності права та правова гарантія безпеки як правове регулювання національних інтересів, створення державними та недержавними інституціями необхідних та достатніх умов для ефективного функціонування правової системи [21, с. 11].

Проблеми правової безпеки та іiї гарантії потребують подальшого теоретико-правового осмислення і не тільки в напрямі з'ясування загального й міждисциплінарного розумінням, але й виявлення своєрідності саме їх правового тлумачення, його імплементації в понятійно-категоріальний апарат юридичної науки, зокрема через співвідношення з такими традиційними юридичними науковими конструкціями як правопорядок, злочинність, правовий вплив, правове регулювання, функції права та держави, гарантії тощо.

Висновки. Попри всі відмінності в розумінні безпеки спільним є таке:

- у «статичному» розумінні безпека розглядається в зіставленні з певними об'єктами (матеріальними та нематеріальними) чи суб'єктами як їх характеристика (властивість), риса.

- в «динамічному» розумінні безпека пов’язується з певною діяльністю, спрямованою на безпеку(ії суб'єктами, засобами, заходами, нормативами, метою тощо), інакше кажучи, на гарантію (захист, охорону) безпеки.

- безпека та її гарантія в різних варіаціях співвідноситься з існуванням, розвитком, цілісністю, незалежністю, спокоєм об'єкта безпеки та відсутністю небезпеки (загроз, ризиків).

- безпека і небезпека мають взаємозалежні виміри, відносні одне одного значення. Так, безпека - це відсутність небезпеки, небезпека за своїм впливом на безпеку - гранична, неприпустима, надмірна, мінімальна, обмежена до прийнятного рівня.

Для розуміння безпеки важливим є їі нерозривність із небезпекою, дуалістичність характеристики об'єкта безпеки як його нормального існування та наявність чи можливість небезпеки при такому існуванні, диференціації безпеки та ії гарантії. Це має суттєве значення і для інтерпретації гарантії безпеки.

Проблеми правової безпеки та ії гарантія потребують подальшого наукового осмислення й не тільки в напрямі з'ясування спільного з їх міждисциплінарним розумінням, але й виявлення своєрідності саме правового розуміння, його імплементації в понятійно-категоріальний апарат юридичної науки, зокрема через співвідношення з такими традиційними юридичними науковими конструкціями як правопорядок, злочинність, правовий вплив, правове регулювання, функції права та держави, гарантії тощо.

\section{Список використаних джерел:}

1. Закон України «Про національну безпеку України». 2018. № 31.

2. Язлюк Б.О. Теоретичні основи сутності та змісту соціально-економічної безпеки. Економічний аналіз : зб. наук. праць / В.А. Дерій та ін. Тернопіль : Видавничо-поліграфічний центр Тернопільського національного економічного університету «Економічна думка». 2014. Том 16. № 1. C. 149-154.

3. Бойко І.В. Дефініції «ризик», «загроза», «небезпека» як об’єкти наукових досліджень у напрямі економічної безпеки підприємства. Приазовський економічний вісник. Класичний приватний університет. Випуск 5(05). 2017 С. 94-98.

4. Семенютіна Т.В. Економічні ризики, небезпеки, загрози: сутність та взаємозв'язок. Економічний простір. № 68. 2012. С. 106-113. 
5. Костюк Ж.С. Поняття ризику, небезпеки та загрози як базових категорій розкриття сутності економічної безпеки підприємства. Вісник економіки транспорту $і$ промисловості. № 43. 2013. C. 142-149.

6. Нижник Н.Р. Національна безпека України (методологічні аспекти, стан і тенденції розвитку : навч. посіб. Ірпінь. 304 с.

7. Малик О.В. Управління ризиками як складова механізму забезпечення фінансової безпеки підприємства. Вісник ОНУ імені Мечникова. 2015. Т. 20. Вип.4. С. 116-120.

8. Постанова Кабінету Міністрів України «Про затвердження Порядку державної реєстрації медичної техніки та виробів медичного призначення» 09.11.2004. № 1497.

9. Наказ МНС України «Про затвердження Методики ідентифікації потенційно небезпечних об’єктів» від 23.02.2006. № 98 .

10. Наказ Мінтрансзв'язку України «Про затвердження Правил сертифікації суб’єктів, що надають послуги з аеронавігаційного обслуговування» від 22.01.2007. № 42.

11. Наказ МВС України «Про затвердження Інструкції з проведення аналізу ризиків у Державній прикордонній службі України» від 11.12.2017. № 1007.

12. Указ Президента України «Про Концепцію боротьби 3 тероризмом в Україні» від 05.03.2019. № 53/2019. № 2163-VIII.

13. Закон України «Про основні засади забезпечення кібербезпеки України» від 05.10.2017.

14. Хиогская рамочная программа действий на 2005-2015 годы : Создание потенциала противодействия бедствиям на уровне государств и общин $(\mathrm{OOH})$ Принята на Всемирной конференции по уменьшению опасности бедствий (Кобе, Хиого, Яронния, 18-22 января 2005 года).

15. Сегеда С.А. Методологічні основи категорії «розвиток»: філософський аспект. Економіка та держава. 2018. № 10. С. 14-22.

16. Мєлєкєсцева Н.В. Категорія наявності/відсутності в логіко-філософському та лінгвістичному аспектах. Проблеми граматики і лексикології украӥнської мови : зб. наук. праць. Серія 10. Київ : Вид-во НПУ імені М.П. Драгоманова. 2011. Вип. 8. С. 167-172.

17. Тер-Акопов АА. Юридическая безопасность человека в Российской Федерации (основы концепции). Государство и право. 2001. № 9. С. 13.

№ 2. C. 11 .

18. Дрейшев Б.В. Правовая безопасность и проблемы ее обеспечения. Правоведение. 1998.

19. Сенякин И.Н. Федерализм - безопасность личности. Конституционное развитие России. Саратов. 1996. С. 106.

20. Тюрина Т.Б. Правовая безопасность личности в современном российском государстве (вопросы теории и практики) : дис. ... канд. юрид. наук : 12.00.01. Саратов, 2005. С. 13-14.

21. Лобода А.М. Правова безпека особи в сучасній Українській державі (теоретикоправове дослідження) : дис. ... канд. юрид. наук : 12.00.01 ; Нац. акад. внутр. справ. Київ, 2013. 19 с

22. Наказ Мінтрансзв'язку України «Про затвердження Правил сертифікації експлуатантів, що здійснюють експлуатацію цивільних повітряних суден (літаків) 3 метою виконання комерційних транспортних перевезень згідно з вимогами OPS 1» від 05.07.2010 № 430. Офіиійний сайт Верховної Ради Украӥни. [Електронний ресурс]. Режим доступу : https://zakon.rada.gov.ua/ laws/show/z0558-10/ed20111007/find?text=\%C7\%E0\%E1\%E5\%E7\%EF\%E5\%F7\%E5\%ED\%ED\%F $\mathrm{F}+\% \mathrm{FF} \% \mathrm{EA} \% \mathrm{EE} \% \mathrm{~F} 1 \% \mathrm{~F} 2 \% \mathrm{~B} 3$.

23. Директива Європейського Союзу «Про встановлення основних норм безпеки для захисту від загроз, зумовлених впливом іонізуючого випромінювання, і скасування директив 89/618/ Євратом, 90/641/Євратом, 96/29/Євратом, 97/43/Євратом і 2003/122/Євратом» від 05.12.2013 № 2013/59/Євратом. Офіиійний сайт Верховної Ради Украйни. [Електронний ресурс]. Режим доступу: https://zakon.rada.gov.ua/laws/show/984_006-13/ed20131205\#n188.

24. Наказ Держатомрегулювання України «Про затвердження Вимог до системи управління якістю проведення діагностичних та терапевтичних процедур з використанням джерел іонізуючого випромінювання» від 03.10.2008 № 166. Офіиійний сайт Верховної Ради Украӥни. [Електронний ресурс]. Режим доступу: https://zakon.rada.gov.ua/laws/show/z1054-08/ed20081109/ find?text $=\%$ C7\% $\% 0 \% \mathrm{E} 1 \% \mathrm{E} 5 \% \mathrm{E} 7 \% \mathrm{EF} \% \mathrm{E} 5 \% \mathrm{~F} 7 \% \mathrm{E} 5 \% \mathrm{ED} \% \mathrm{ED} \% \mathrm{FF}+\mathrm{FF} \% \mathrm{EA} \% \mathrm{EE} \% \mathrm{~F} 1 \% \mathrm{~F} 2 \% \mathrm{~B} 3$.

25. Наказ МВС України «Про затвердження Правил техногенної безпеки» від 05.11.2018 № 879 / Офіційний сайт Верховної Ради України. [Електронний ресурс]. Режим доступу: https://zakon.rada.gov.ua/laws/show/z1346-18/ed20181105\#n20.

26. Наказ Мінтранс України «Про затвердження Правил сертифікації аеропортів» від 05.07.2004 № 569. Офіиійний сайт Верховної Ради Украйни. [Електронний ресурс]. Режим доступу: https://zakon.rada.gov.ua/laws/show/z0924-04/ed20060228/find?text=\%C7\%E0\%E1\%E5\%E 
$7 \% \mathrm{EF} \% \mathrm{E} 5 \% \mathrm{~F} 7 \% \mathrm{E} 5 \% \mathrm{ED} \% \mathrm{ED} \% \mathrm{FF}+\% \mathrm{E} 0 \% \mathrm{E} 2 \% \mathrm{~B} 3 \% \mathrm{E} 0 \% \mathrm{~F} 6 \% \mathrm{~B} 3 \% \mathrm{E} 9 \% \mathrm{ED} \% \mathrm{EE} \% \mathrm{BF}+\% \mathrm{E} 1 \% \mathrm{E} 5 \%$ $\mathrm{E} 7 \% \mathrm{EF} \% \mathrm{E} \% \mathrm{EA} \% \mathrm{E} 8$.

27. Наказ МВС України «Про організацію службової діяльності поліції охорони з питань забезпечення фізичної охорони об'єктів» від 07.07.2017 № 577. Офіиійний сайт Верховної Ради України. [Електронний ресурс]. Режим доступу : https://zakon.rada.gov.ua/laws/show/z0989-17/ ed20170707\#n35.

28. Закон України «Про забезпечення безпеки осіб, які беруть участь у кримінальному судочинстві» від 23.12.1993 № 3782-XII. Офіційний сайт Верховної Ради Украйни. [Електронний peсурс]. Режим доступу: https://zakon.rada.gov.ua/laws/show/3782-12/ed20090611/find?text=\% $\%$ C7\%

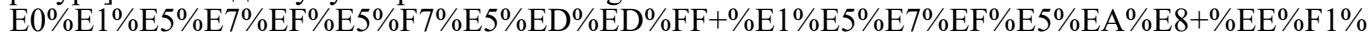
B3\%E1,+\%FF\%EA $\%$ B3 $+\%$ E $1 \%$ E5\%F0\%F3\%F2\%FC+\%F3\%F7\%E0\%F $\%$ F $2 \%$ FC+\%F3+\%EA $\%$ F0\%E8\%EC\%B3\%ED\%E0\%EB\%FC\%ED\%EE\%EC\%F3+\%F1\%F3\%E4\%EE\%F7\%E8\%ED\%F1\% $\mathrm{F} 2 \% \mathrm{E} 2 \% \mathrm{~B} 3$.

29. Закон України «Про охорону атмосферного повітря» від 16.10.1992 № 2707-XII. Офіиійний сайт Верховної Ради Украӥни. [Електронний ресурс]. Режим доступу: https://zakon.rada.gov.ua/laws/show/2707-12/ed20171218\#n18.

30. Наказ Управління державної охорони «Про затвердження Порядку забезпечення безпеки посадових осіб, щодо яких здійснюється державна охорона у місцях постійного та тимчасового перебування» від 27.05.2011 № 210. Офіціийний сайт Верховної Ради Украйни. [Електронний pecypc]. Режим доступу: https://zakon.rada.gov.ua/laws/show/z0700-11/ed20110629/find?text=\% $\mathrm{CE} \% \mathrm{~F} 5 \% \mathrm{EE} \% \mathrm{~F} 0 \% \mathrm{EE} \% \mathrm{ED} \% \mathrm{E} 0$.

31. Наказ Міноборони України «Про затвердження Правил розслідування авіаційних подій та інцидентів в авіації Збройних Сил України (Класифікатор подій, які належать до інцидентів)» від 19.05.2010 № 256. Офіиійний сайт Верховної Ради України. [Електронний ресурс]. Режим доступу: https://zakon.rada.gov.ua/laws/show/z0386-10/ed20100629/find?text $=\% \mathrm{C} 7 \% \mathrm{E} 0 \%$

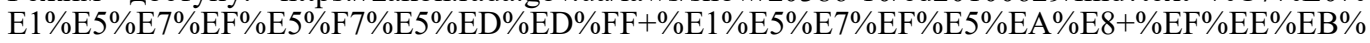
$\mathrm{FC} \% \mathrm{EE} \% \mathrm{~F} 2 \% \mathrm{~B} 3 \% \mathrm{E} 2$.

32. Наказ Міноборони України «Про затвердження Правил інженерно-авіаційного забезпечення державної авіації України» від 05.07.2016 № 343. Офіційний сайт Верховної Ради України. [Електронний ресурс]. Режим доступу: https://zakon.rada.gov.ua/laws/show/z1101-16/ ed20160705\#n32.

33. Закон України «Про основні засади забезпечення кібербезпеки України» від 05.10.2017 № 2163-VIII. Офіuійний сайт Верховної Ради Украӥни. [Електронний ресурс]. Режим доступу: https://zakon.rada.gov.ua/laws/show/2163-19/ed20171005\#n13.

34. Наказ Держатомрегулювання «Про затвердження Вимог з ядерної та радіаційної безпеки до інформаційних та керуючих систем, важливих для безпеки атомних станцій» від 22.07.2015 № 140. Офіиійний сайт Верховної Ради України. [Електронний ресурс]. Режим доступу: https://zakon.rada.gov.ua/laws/show/z0954-15/ed20150722\#n37.

35. Кодекс цивільного захисту України від 02.10.2012 № 5403-VI. Офіщійний сайт Верховної Ради України. [Електронний ресурс]. Режим доступу: https://zakon.rada.gov.ua/laws/ show/5403-17/ed20150211\#n101.

36. Наказ Міноборони України «Про затвердження Інструкції про порядок виконання норм міжнародного гуманітарного права у Збройних Силах України» від 23.03.2017 № 164. Oфiųiüний сайт Верховної Ради України. [Електронний ресурс]. Режим доступу: https://zakon.rada.gov.ua/ laws/show/z0704-17/ed20170323\#n176.

37. Резолюція Ради Європи «Про право на відповідь - стан особи відносно преси» від 02.07.1974 № (74)26. Офіиійний сайт Верховної Ради Украӥни. [Електронний ресурс]. Режим доступу: https://zakon.rada.gov.ua/laws/show/994 741/ed19740702/find?text=\%E7\%E0\% $\% 1 \% \mathrm{~B} 3 \% \mathrm{E} 1+$ $\% \mathrm{E} 7 \% \mathrm{E} 0 \% \mathrm{~F} 5 \% \mathrm{E} 8 \% \mathrm{~F} 1 \% \mathrm{~F} 2 \% \mathrm{~F} 3+\% \mathrm{EF} \% \mathrm{~F} 0 \% \mathrm{E} \overline{0} \% \mathrm{E} 2 \% \mathrm{E} 0$.

38. Закон України «Про адвокатуру та адвокатську діяльність» від 05.07.2012 № 5076-VI. Офіиійний сайт Верховної Ради Украӥни. [Електронний ресурс]. Режим доступу: https://zakon.rada.gov.ua/laws/show/5076-17/ed20150206/find?text=\%E7\%E0\%F5\%E8\%F1\%F2+-\#n12.

39. Директива Європейського Союзу «Про ідентифікацію і визначення європейських критичних інфраструктур та оцінювання необхідності покращення їх охорони та захисту» від 08.12.2008 № 2008/114/ЄС. Офіиійний сайт Верховної Ради України. [Електронний ресурс]. Режим доступу: https://zakon.rada.gov.ua/laws/show/984_002-08/ed20081208\#n45.

40. Про інформацію: Закон України від 02.10.1992 № 2657-XII. Офіційний сайт Верховної Ради України. [Електронний ресурс]. Режим доступу: https://zakon.rada.gov.ua/laws/show/ 2657-12/ed20170101\#n21. 